\title{
A Survey of Amish Tunebooks: \\ Categorizing Slow Tunes by Date of Origin
}

\author{
Gracia Schlabach $^{1}$ \\ Lyndonville New Order Amish Church
}

\begin{abstract}
A survey of Notabücher (tune books) currently used by geographically diverse Amish communities leads to the conclusion that Amish slow tunes can be placed into three categories according to date of origin. I've dubbed these Old, Middle, and New Groups. Old Group tunes are derived from sixteenth century folk songs and Reformation era hymns. Middle Group tunes are, for the most part, based on later German chorales and New Group tunes have been adapted from early American hymn tunes. I begin this article with a brief summary of earlier research on Amish slow tunes, then give an overview of current Notabücher, their compilers, and layout. Next, characteristics of each tune category are given, with musical examples. Lastly, the Notabuch survey appears in chart form.
\end{abstract}

\section{Keywords}

Ausbund, Eine Unparteiische Liedersammlung (B), Unparteiische Liedersammlung (G), Unparteyisches Gesang-Buch, Notabücher, hymn, slow tune, half-fast tune 


\section{Introduction}

Our small New Order Amish congregation in western New York sings at least three Ausbund songs at each church service. Like nearly all other Amish groups, we use the typical slow style, sung in unison and loaded with melismas. A solo singer leads the first syllable of each line. Thus, we perpetuate a singing style that has been transmitted aurally for more than four centuries (Yoder, et al. 1964). This distinctive style has been called Amish church music (Hohmann 1959), Amish church tunes (Wagler 1985), and the Amish singing style (Durnbaugh 1998). The term “slow tune," which I prefer, is a direct translation of our Pennsylvania German term schloh Weis.

Amish have a rich German hymn tradition using four German hymnals (Schlabach 2011) and three basic styles of singing. With few exceptions, varied groups of Amish across North America use slow tunes in worship services including wedding ceremonies, baptismal services, and communion services. Half-fast (halb stark) tunes are used at slightly less formal occasions such as the parting song in church services or at Sunday school among certain Amish. Other occasions that call for half-fast tunes are viewings, wakes and funerals, and afternoon / evening singings at weddings. The term half-fast is relative, both in interpretation and practice. The term "half-slow" might be more accurate because these tunes share many characteristics of slow tunes, including being sung in unison, having a slowed tempo, and having additional connecting notes. Over time, half-fast tunes tend to take on increasing slow tune attributes.

Fast tunes (starke Weise), borrowed from contemporary English hymnals and matched to German texts, are used at home, at school, or at young folks' singings. The English chorus, or its German translation, of a tune is often inserted between the verses. Although most Amish do not sing parts, a few use two- or even four-part harmony.

\section{Early Research on Slow Tunes}

Nearly three centuries of Amish singing passed before any definitive musical research on our slow tunes took place. In the mid twentieth century, when the Amish overall attracted greater interest from the outside world, our slow tunes, especially, received a good deal of attention. Researchers listened to Amish singing and made recordings. They transcribed selected tunes and a number of them delved into the history of this unusual style (Umble 1939; Yoder 1942; Jackson 1945, 1946; Nettl 1957; Hohmann 1959).

These early studies are becoming dated for several reasons. First, these researchers concentrated mostly on whether or not Amish hymn tunes still followed the tune suggestions given in the Ausbund; they did not consider the broader spectrum of Amish tunes. Second, later studies explored in greater detail musicological aspects directly or indirectly related to Amish singing (Sommers 1972; Temperly 1981; Durnbaugh 1998; Riall n.d.). Most significantly, early studies were made before the widespread use of Notabücher, or tune books that are compiled by 
Amish singers to assist in learning and transmitting the tunes. Nevertheless, early studies are still useful for their descriptions of the slow tune style and rudimentary theories of its development.

The availability of Amish Notabücher opens up a treasure trove of opportunity for the musicologist. I consider my categorization of tunes into Old, Middle, and New Groups quite preliminary. By placing the tunes in a systematic listing by meter, I have attempted to provide a format for exploration. How many slow tunes exist? How much variation is there between communities? What is the origin of a particular tune and how widespread is its use?

\section{Notabücher}

All Amish Notabücher contain music for slow tunes used with Ausbund texts. Some communities use one of two smaller books, Eine Unparteiische Liedersammlung (B) and Unparteiische Liedersammlung (G), instead of the Ausbund. Others use them as supplemental books besides the Ausbund. Both contain Ausbund material (Schlabach 2011). Most Notabücher also include tunes, both slow and half-fast, for texts in these smaller hymn books and not in the Ausbund. Notabücher are closely connected to the Scripture registers that guide song selection in Amish services (Schlabach 2012).

A booklet simply titled Notabuch compiled by Noah L. Hershberger, then of Holmes County, Ohio, led the way in tunebook format. It was published in 1984 and had ten printings by 2006. This book is available in two sizes, a 4" x 6" spiral bound and a smaller pocket size with staples. A translation from its German foreword says, "This book is not to be used as a rule book. Many songs are not sung exactly same from one area to the other. Each one may adapt tunes to his taste ... all for the glory of God.”

In 1997, Ausbund and Liedersammlung Songs with Shaped Notes was compiled by Ben Troyer Jr. with the assistance of eleven others, and published by Carlisle Press. It covered the same greater Holmes County area tunes as Hershberger's but used shaped notes instead of round. This book, now in its eighth printing, is $4 \frac{1}{4}$ " x 6". Part of the acknowledgment reads, “Above all, may the Lord be glorified and His church be edified with the singing of these songs."

Schöne Alte Weisa von Ausbund und Liedersammlung uses the same page and index formats as Carlisle's but with round notes. Jacob Yoder of Danville, Ohio, and seven other men compiled this collection of not-so-common slow and half-fast tunes in 2001. A German sentence introduces the book, "We tried to put this book together with old tunes as we had learned them."

Geauga Church Songs is an undated booklet that says "1st edition,” but also "revised by Bill S. Farmwald, Munfordville, Kentucky.” Its size is 5" x 4" and the notes are drawn by hand.

The first Lancaster County, Pennsylvania, tunebook, Nota für das Ausbund, was printed in 1990 using shaped notes drawn by Katie Stolzfoos, which were in a loose-leaf format earlier. The music had key signatures, and notes showed duration. This book underwent four reprints 
before a major revision was made. The foreword of the 2011 edition, compiled by Jonas Beiler of Lebanon County, explains, “The reason of the revision was not to keep up with the times, but rather the opposite, to try and preserve the singing from an earlier generation. This time there was a large group getting together to decide on the changes. In 2005 the revised edition was brought into print, with also some more Lieder added (see Anhang). This book is intended to be used as a guide and not as a ruler. Each person may sing as he was taught and feels is right...This book is not intended to be used in church services.” The 2011 edition also includes Lieder und Schriften, a scripture register. Its $5 \frac{1}{2} 2$ x 8 1/2" format is larger than any of the Ohio tunebooks.

Old Order Church Tunes for Somerset County, Pennsylvania - 1984 consists of 8 1/2" x 11" loose-leaf pages in a binder. The words are handwritten. Shaped notes show timing, but there are no key signatures. The Amish of Somerset Co. use Eine Unparteiische Liedersammlung (B).

Three tunebooks having a very similar format are Ausbund Lieder Mit Noten for LaGrange County, Indiana, and St. Joseph County, Michigan; Ausbund Lieder Mit Noten Nappanee area; and an unnamed, undated Notabuch revised in 1992 by Henry Yoder of Bethany, Missouri. This book includes Scripture registers for Bloomfield, Iowa; Johnson and Washington Counties, Iowa; and Arthur, Illinois. All have round notes with key signatures. All three appear to be based on notes written earlier by Olen F. Yoder, of Middlebury, Indiana. Some material was also taken from Wacht \& Leiche Lieder, now out of print, by Willie Christner of Nappanee, Indiana. The Indiana books are 4" x 3 1/2", the other, 5" x 4 1⁄2".

The Nappanee first edition was in 1999; Mervin S. Bontrager added songs from pages 38-52 in the second edition in 2004. The newer LaGrange County 2006 edition copyrighted by Freeman L. Yoder, Middlebury, says

No copying or printing from songs on pages 1-63 of this booklet without permission from F. L. Yoder. This request is made so there will be less confusion if there would be different "nota” books for the same area. You may make corrections in your own "nota" books for your area... Alles zu Gottes ehre [all to the glory of God].

The Amish of Kalona, Iowa now have their own tunebook, Singet dem Herrn Nota Buch, new in 2013. The acknowledgments read

We greatly appreciated the Ohio Nota Book with shaped notes [Carlisle] which served as a reliable pattern for many of our songs. Also to a number of brethren, in taking time to check out the notes for Johnson County accuracy... Through the willing hands and hearts of our fellow men, our Lord sends his blessings. May he alone be given praise and glory.

This tunebook has only Liedersammlung B songs.

\section{Notabuch Layout}

Notabuch layout reveals key elements of the Amish slow tune. In most books, songs are 
arranged by meter number as given in the Ausbund. Tunes are usually interchangeable for songs having the same meter, although many tunes are deeply associated with a certain text and rarely interchanged. The lines of the songs are numbered to show how the melody repeats itself on certain lines. Most use round notes to show pitch. Lancaster, Somerset, Carlisle, and Kalona use shaped notes. A few accidentals are used. Only Lancaster uses key signatures. Notes do not show duration, except for Lancaster and Somerset.

Tune names appear either above the music or in the index. Tune names came about in a number of ways. They may be taken from the page number of a text (e.g. 706), the occasion in which the text is commonly used (e.g. Hochzeit, wedding), the subject of a text (e.g. Fußwasch, footwashing) or a phrase within the text (e.g. Oelkauf, purchase of oil).

Will written music enhance or erode the longstanding oral tradition? Only time will tell. For now, it provides an excellent reference for those learning the tunes.

\section{Old Group Slow Tunes}

Characteristics of Old Group slow tunes are as follows:

- Have the most elaborate melismata, up to nine tones per syllable.

- Have the greatest musical consistency between communities.

- Make use of a minor scale.

- Have a wide adaption to various meters by adding or rearranging lines.

- Have a strong connection to a specific text with consistent usage among Notabücher.

- Tune names derived from phrase in text or its page number, or the occasion in which the song is used.

- Tune names generally consistent.

Old Group slow tunes are used as the opening songs in practically all Amish services, including Sunday worship, Communion, wedding services, council services, and baptismal services. The Lob Lied, always sung second in Amish services, is part of the group. Another excellent example is the 766 Weis, also known as Oelkauf Weis, since the text refers to the parable of the ten virgins and the purchase of oil, or Tholer Weis, after the tune suggestion given in the Ausbund. The root melody is "Herr Christ der einig Gott's Sohn" (Zahn 4297) from the Lochamer Liederbuch. This collection of folktunes was made in Nuremburg, Germany, between 1455 and 1460. The 766 Weis is sung to more Ausbund texts than any other slow tune. It has been adapted to various meters by repeating the first two lines as needed or adding an extra syllable to the last line.

Old Group slow tunes often have counterparts among other Anabaptists groups who practice similar slow singing. The 766 Weis is related to the Hutterite song "Gross Freud hab ich im Herzen" and the Old Colony Mennonite 72. Melodie. Apparently each group utilized the same root melody and added the trills and wavers of their own distinctive style. 


\section{Middle Group Tunes}

Characteristics of Middle Group Tunes are as follows:

- Meter patterns of songs added to later editions of the Ausbund or songs not in the Ausbund at all.

- Melody line averages three to five tones per syllable.

- Have a clearer connection to the root melody than Old Group tunes.

- Tunes usually not used as an opening hymn in services.

- Some considered half-fast.

- Usually a strong connection to a certain text.

- More regional use.

Middle Group Tunes present a good deal of ambiguity. For the most part they represent the popular meters used by German hymn writers in the 1600s and 1700s. Many songs in Unparteysiches Gesang-Buch and in both Liedersammlung were taken from Lutheran, Pietist, and Reformed collections. Some Middle Group Tunes may also represent a New Group tune that is undergoing a shift toward becoming slower.

Various tunes in this Middle Group have counterparts among tunes used by Old Order Mennonites. Many of their slow tunes, although not as slow as Amish tunes, are based on tunes of this era as preserved in the Philharmonia.

The Grab Lied (burial song) used in Holmes County, Ohio, is a good example of a Middle Group Tune. It is based on a Geneva 42, a tune from the French Psalter of the 1560s. These entered Mennonite hymnody through the translations made by Ambrosius Lobwasser, a German Lutheran. Lobwasser Psalms were placed in a separate section at the front of Unparteysiches Gesang-Buch.

\section{New Group Tune}

Characteristics of New Group Tunes are as follows:

- Usually have no more than three tones per syllable.

- Simpler melody lines than Old or Middle Group tunes.

- Show a clear connection to the root melody. Most are in a major scale and are brighter in mood and a bit faster (Yoder 1964).

- Some considered half-fast; others fully accepted as slow tunes but used at the end of services or on less formal occasions.

- Tune names most variable.

- Tune names often based on location, such as the source or simply the area from which one learned it, or a person's name, either the individual who introduced it to his home area, a song leader who often picked the song, or in fewer cases, the composer.

- Many are two-line Weis or "hung together." Final syllable of one line is linked to beginning of next. Everyone, not just the song leader, sings the next line's first syllable. 


\section{Figure 1: Example of an Old Group Slow Tune}

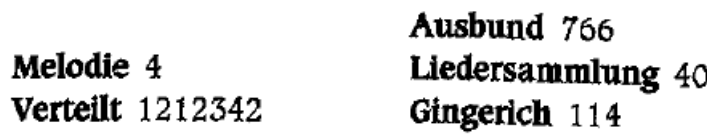

Ausbund 766

Verteilt 1212342

Gingerich 114
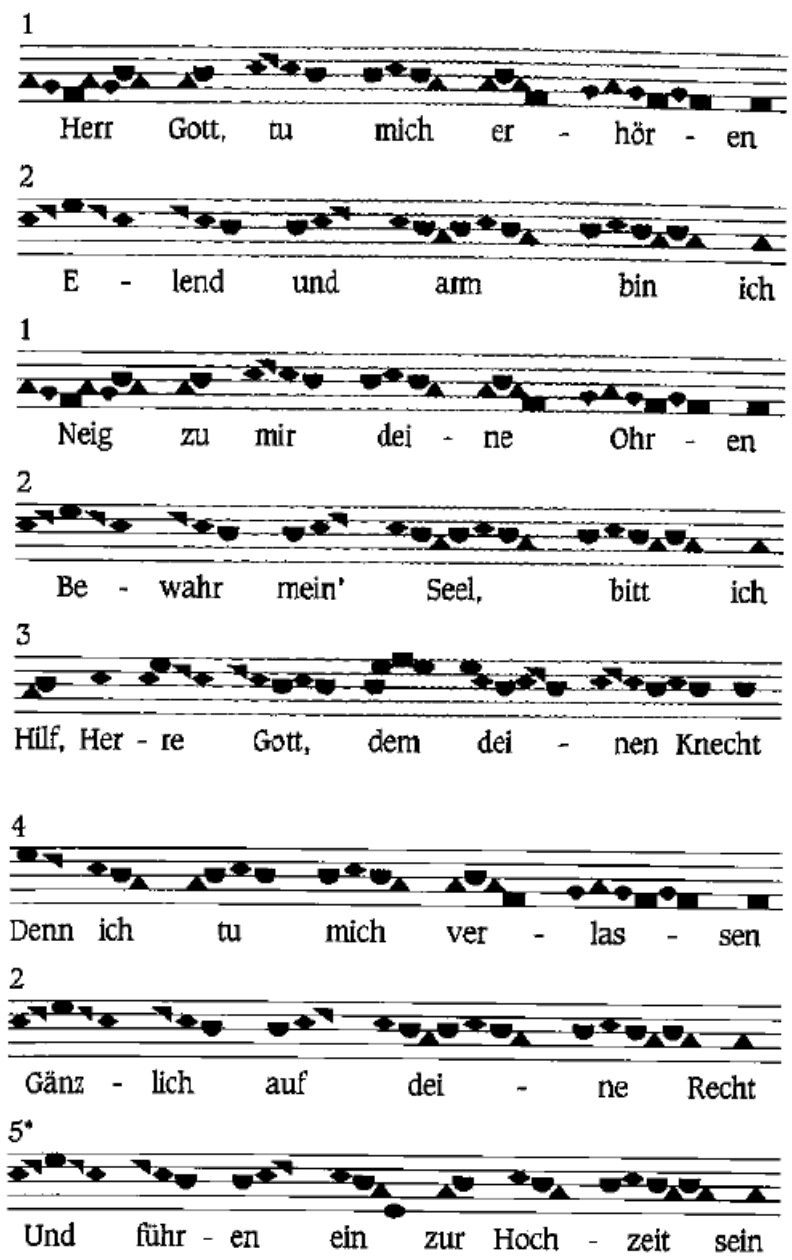

Andere Lieder auf die nämlich Weisz

Ausbund 700

$\begin{array}{ll}\text {-649 v. } 4 & 1212345 \\ \text { All } 2 \text { Melodie } & 121212342 \\ \text { All } 4 \text { Melodie } & 1212342\end{array}$

From Ausbund \& Lieder Sammlung Songs by Ben Troyer Jr. Used by permission. 
Figure 2: Example of a Middle Group Tune

Grab Lied
Melodie
Verteilt $1 \& 21 \& 2345 \& 6$

Ausbund

Liedersammlung 189

Gingerich 292

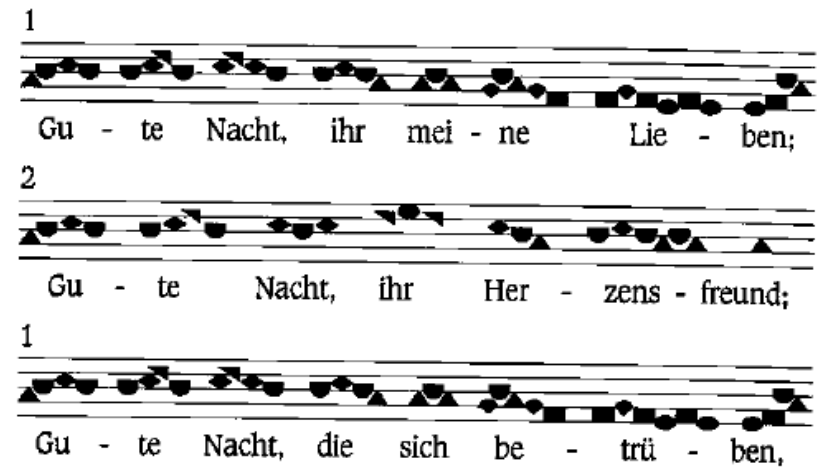

2

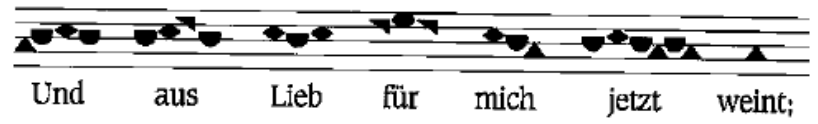

3

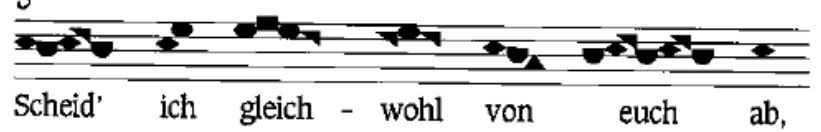

4

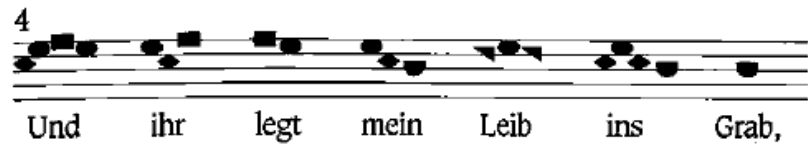

5

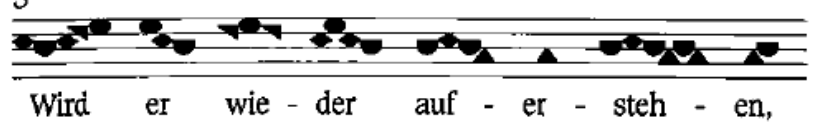

6

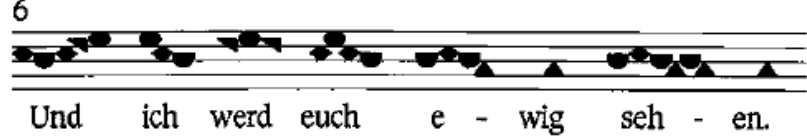

From Ausbund \& Lieder Sammlung Songs by Ben Troyer Jr. Used by permission. 
Most New Group tunes are based on early American folk hymns or hymn tunes that were written from the mid-1700s to the late 1800s. After they were slowed down and had connecting notes added between tones and, in some cases, underwent slight changes in the melody, they became part of the Amish slow and half-fast tune repertoire. Many entered as wake and funeral songs, the greatest area of innovation among Amish tunes.

One example is Rockbridge. The first known publication of this early American folk hymn tune occurred in 1812 on a sheet of tunes printed for John Logan, a North Carolina singing school teacher. It may have had its start as an Amish tune through its publication in Die Neue Choral Harmonie, compiled in 1844 by S.M. Musselman, Lower Salford, Montgomery County, Pennsylvania. This was the first Mennonite tune book in America with notes; it had the old oblong style. Here it was paired with the text "O Jesu Christ mein Lebens Licht." It is again paired with these words in Amische Lieder. Apparently, it became more closely associated with "Es sind zween Wag" later. In most areas, this song is sung with lines three and four joined, but in Lancaster and Kalona, they are separated.

\section{Figure 3: Example of a New Group Tune}
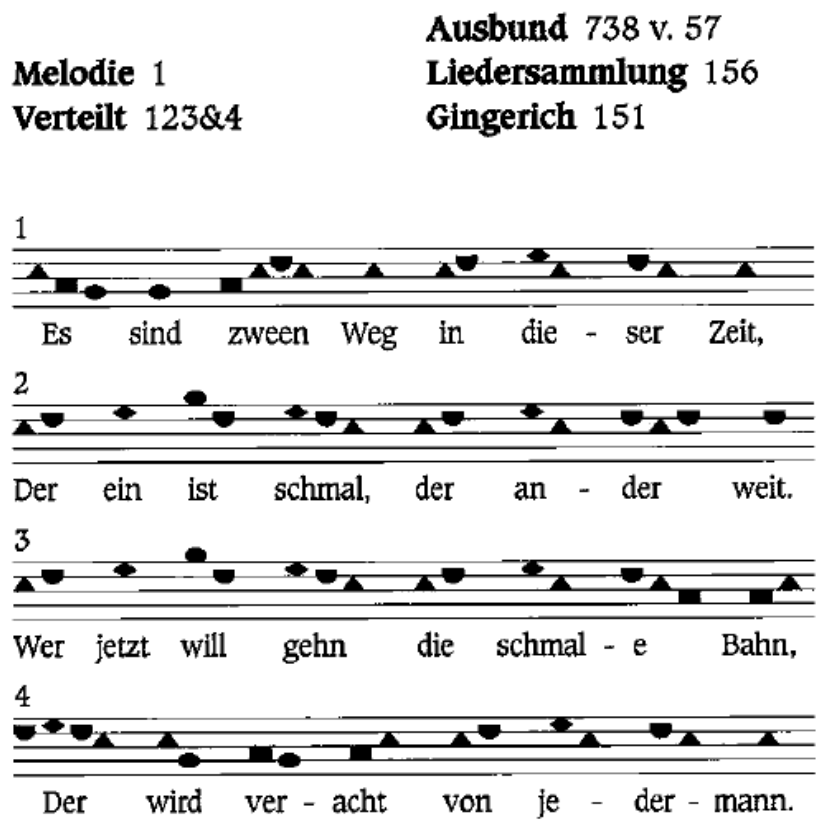

From Ausbund \& Lieder Sammlung Songs by Ben Troyer Jr. Used by permission. 


\section{Amish Slow and Half-Fast Tunes}

This chart includes all tunes from eight Notabücher in print in 2013. For comparison's sake, corresponding tunes from Amishe Lieder (Yoder 1942) and The Church Music of the Old Order Amish of the United States (Hohmann 1959) are also included.

Tunes are divided into three groups according to hymnal: Ausbund, Eine Unparteiische Liedersammlung (B), and Unparteiische Liedersammlung ( $G)$. In some communities, one of the Liedersammlung is used to supplement the Ausbund, or perhaps replaces it completely. In such cases, tunes for Ausbund texts are used with the same texts in a Liedersammlung.

I sought to provide a more systematic way to identify Amish tunes. Ideally, Amish tunes ought to have a consistent name or number, for example, something similar to Köchel's numbering of works by Mozart. This chart is a step in that direction. I welcome information about tunes not recorded in any Notabuch.

\section{Key to Chart}

Meter: In the Ausbund, texts are assigned a number according to their metrical pattern (Melodie). For example, all texts having Long Meter are called 1 Melodien. This chart lists tunes according to their Ausbund meter number beginning with 1. Texts sharing the same meter are then ranked by Ausbund page numbers in numerical order, then tunes with wide use before tunes with localized use.

Certain tunes are adapted to fit yet another meter either by having the repeating patterns for the lines rearranged, added, or abbreviated, or syllables within lines added or omitted. Such tunes are listed directly under their parent tune, separated by dotted lines.

Notabücher have different ways of showing adapted tunes. If it has only slight adaptations, there may only be some comments on the same page as the parent tune. Tunes with major rearranging are sometimes treated as separate tunes with their own notes. The Notabuch location column shows how various adapted tunes are treated in their respective Notabuch.

Page number: Tunes for Eine Unparteiische Liedersammlung (B) and Unparteiische Liedersammlung $(G)$ are listed by page numbers in numerical order.

Texts: Texts are listed by Ausbund page number, in order of use frequency. The texts listed here are not exhaustive.

Tune name: These are given whenever possible, but many tunes do not have names. Localized names are marked with their Notabuch abbreviation key.

Date of origin: These designations are mine. Many are quite preliminary and are intended to be a starting point for further research. Question marks indicate the best estimate. 
Source: these are mine, and again, there are many gaps. I did not include suggested origins by Hohmann (1959) and Jackson (1945) because several are obviously in error. Still, they provide a lead for further research.

Notabuch location: Key letters are followed by page number, except for Somerset, which uses song number. If a Notabuch does not contain music for this tune, its letter is omitted. Lowercase “a” indicates top of page; "b,” bottom.

\section{Notabuch Key}

C Carlise Press, Holmes County, Ohio

G Geauga County, Ohio

$\mathrm{H}$ Hershberger, Holmes County, Ohio

I Indiana, LaGrange County

K Kalona, Iowa

L Lancaster County, Pennsylvania

M Missouri (Henry Yoder)

N Nappanee, Indiana

S Somerset County, Pennsylvania

A Amische Lieder, 1942

Ho Hohmann, 1959

\section{Table 1: Tunes Used with Ausbund Texts}

\begin{tabular}{|c|c|c|c|c|c|}
\hline Meter & Texts & Tune Names & Origin & Source & Notabuch Location \\
\hline 1 & 5 & Fünf, Wir glauben (K) & Old & & $\begin{array}{l}\text { C1, G10, H4, I6, K11, L22b, } \\
\text { M6, N6, S5, }\end{array}$ \\
\hline 9 & 272 & & & & $\mathrm{~L} 22$ \\
\hline 11 & 453 & Schneider(K) & & & L34 (CGHIMNS see 5) \\
\hline 1 & $\begin{array}{l}46,217 \\
449\end{array}$ & Pfingst & Old & $\begin{array}{l}\text { Christe, der du } \\
\text { bist Tag und Licht }\end{array}$ & $\begin{array}{l}\text { C3, G6a, H6, I18, K40, } \\
\text { L21b, M18, N18, S31, A11, } \\
\text { Ho119, } 219\end{array}$ \\
\hline 1 & 46 & 100 Year Weis & New? & & G6b \\
\hline 1 & 46 & Hochzeit(Y) & New & Hebron & C80, G2, Y11 \\
\hline 1 & $\begin{array}{l}738 v 57, \\
46\end{array}$ & Yost Yoder (K) & New & Rockbridge & $\begin{array}{l}\text { C6, G4a, H9, I9b, K44, } \\
\text { L17b, M9b, N9b, S20, A48 }\end{array}$ \\
\hline 1 & 738 & & Middle? & & L45a, A25, Ho130 \\
\hline 1 & $738 v 57$ & & New & $\begin{array}{l}\text { Uxbridge, } \\
\text { Tremore, or } \\
\text { Waldeck? }\end{array}$ & L46a \\
\hline $1 \mathrm{~A}$ & 5 & & Middle? & & L16, A24a, Ho172 \\
\hline $1 \mathrm{~A}$ & 89 & & Middle? & & L18b \\
\hline $1 \mathrm{~A}$ & 712 & $\begin{array}{l}\text { Hochzeit, Hochzeitlich } \\
\text { Kleid (K) }\end{array}$ & Old & & $\begin{array}{l}\text { C5, G5, H8, I31a, K12, L43, } \\
\text { M31, N31a, S6, A38, } \\
\text { Ho136,189 }\end{array}$ \\
\hline $1 \mathrm{~A}$ & 35 & $\begin{array}{l}\text { Funf und Dreißig }(\mathrm{H}), \\
\text { Blaurock }\end{array}$ & Old & & $\begin{array}{l}\text { C2, G3, H5, I31, K13, L17a, } \\
\text { M31b, N31b, S7, Ho213,228 }\end{array}$ \\
\hline
\end{tabular}




\begin{tabular}{|c|c|c|c|c|c|}
\hline $1 \mathrm{~A}$ & 131 & Indiana Weis (G) & New & & G7, L20a \\
\hline $1 \mathrm{~A}$ & 868 & Tobias Lied & Middle & & C75, G12, H75, M58 \\
\hline 2 & 464 & & Middle? & & L54 \\
\hline 3 & 1 & Levi Wengerd Weiß (Y) & Middle & $\begin{array}{l}\text { Es ist das Heil uns } \\
\text { kommen her }\end{array}$ & G47, Y41 \\
\hline 3 & 411v8 & Groß Gemein & Old & & $\begin{array}{l}\text { C8, G41, H11, I20, L31, } \\
\text { M20, N20, S3, A2 }\end{array}$ \\
\hline 3 & 445 & Merkt Auf & Old & & $\begin{array}{l}\text { C10, G44, H12, I11, K3, } \\
\text { M11, N11, S2 }\end{array}$ \\
\hline 3 & 655 & & & & L41, (CGHILMN see 445 ) \\
\hline 17 & 554 & & & & L38, (CGHIMN see 455) \\
\hline 3 & 452,329 & Ernt & New? & & $\begin{array}{l}\text { C12, G46, H13, I24, K4, } \\
\text { L33, M24, N24, A2 }\end{array}$ \\
\hline 3 & 655 & Joe Miller & New & $\begin{array}{l}\text { composed by Joe } \\
\text { Miller (1862- } \\
\text { 1946) }\end{array}$ & I43,62, K88, L55, M42 \\
\hline 3 & 666 & Groß Gma (G), Mose (K) & Old & & $\begin{array}{l}\text { C14, G42, H14, I17, K6, } \\
\text { L43, M17, N17 }\end{array}$ \\
\hline 8 & $\begin{array}{l}254 \mathrm{v} 11 \\
\text { or } 20\end{array}$ & & & & $\begin{array}{l}\text { L51, (CGHIMN do not list } \\
\text { separate notes) }\end{array}$ \\
\hline 3 & 770 & Lob Lied & Old & Aus tiefer Not & $\begin{array}{l}\text { C16, G45, H15, I1, K1, } \\
\text { L48a, M1, N1, S1, A1, } \\
\text { Ho155,202,234 }\end{array}$ \\
\hline 3 & 789, 329 & $\begin{array}{l}\text { Scheid Lied, Scheid } \\
\text { Verhanden (K) }\end{array}$ & Middle? & & $\begin{array}{l}\text { C18, G43, H16, I28, K5, } \\
\text { L26, M28, N28, A19, Ho121 }\end{array}$ \\
\hline 4 & 70449 & Mägdelein & Middle? & & $\begin{array}{l}\text { C4, G1, H7, I34, K45, L18a, } \\
\text { M34, N34a }\end{array}$ \\
\hline 4 & 310 & $\begin{array}{l}\text { Ordnungs Gma, Durch } \\
\text { Gnad (K) }\end{array}$ & Old & & $\begin{array}{l}\text { C20, G53, H17, I16, K15, } \\
\text { L24a, M16, N16, S9, A6, } \\
\text { Ho126,185 }\end{array}$ \\
\hline 4 & 378 & $\begin{array}{l}\text { Hochzeit, Christi Braut } \\
\text { (K) }\end{array}$ & Old & & $\begin{array}{l}\text { C24, G49, H18, I30, K14, } \\
\text { L29, M30, N30, S8, A37 }\end{array}$ \\
\hline 4 & 385 & Tage Weiß & Old & & $\begin{array}{l}\text { C26, G52, H19, I2, K63, } \\
\text { M2, N2 }\end{array}$ \\
\hline 4 & 766700 & $\begin{array}{l}\text { Oehlkauf (C), Tholor (H), } \\
\text { Herzen Loben (K) }\end{array}$ & Old & $\begin{array}{l}\text { Herr Christ der } \\
\text { einig Gott's Sohn }\end{array}$ & $\begin{array}{l}\text { C22, G48, I23, K17, M23, } \\
\text { N23, S29 (H does not list } \\
\text { separate notes) }\end{array}$ \\
\hline 2 & 530 & & & & $\begin{array}{l}\text { H10, }(\mathrm{C} \text { does not list } \\
\text { separate notes }\end{array}$ \\
\hline $21 /$ & $649 \mathrm{v} 4$ & $\begin{array}{l}\text { Hochzeit }(\mathrm{G}) \text { Herzen } \\
\text { Loben }(\mathrm{K})\end{array}$ & & & $\begin{array}{l}\text { G4, K56, L37, (CIMN list } \\
\text { extra line with 766, H with } \\
530 \text { ) }\end{array}$ \\
\hline 4 & 766 & & New & & L47a \\
\hline 5 & $\begin{array}{l}209,404, \\
563\end{array}$ & $\begin{array}{l}\text { Grasshopper (C), } \\
\text { Stepladder (G), } \\
\text { Heuschrecke (H), Ewig } \\
\text { Vater }(\mathrm{K})\end{array}$ & Middle & & $\begin{array}{l}\text { C28, G50, H20, I33, K96, } \\
\text { L19b, M33, N33, A32 }\end{array}$ \\
\hline 5 & 563 & $\begin{array}{l}\text { Jonas Yoder (C), Ein Alte } \\
\text { Weis }(\mathrm{H})\end{array}$ & Middle & & $\begin{array}{l}\text { C29, H21, I10, L38b, M10, } \\
\text { N10, A8 }\end{array}$ \\
\hline 5 & 706,563 & $\begin{array}{l}\text { Siebenhundertsechs }(\mathrm{H}) \text {, } \\
\text { Wagner }(\mathrm{K})\end{array}$ & Old & & $\begin{array}{l}\text { C30, G51, H22, I13, K62, } \\
\text { L44, M13, N13, S32, Ho194 }\end{array}$ \\
\hline
\end{tabular}




\begin{tabular}{|c|c|c|c|c|c|}
\hline 6 & 110 & Canada (Y) & New & & C31, Y42 \\
\hline 6 & 314 & Wahre Liebe (K) & New? & & $\begin{array}{l}\text { C40, G23, H26b I26, K21, } \\
\text { M26, N26, S11 }\end{array}$ \\
\hline 6 & 314 & Kansas & New & & 160 \\
\hline 6 & 393 & Schweizer & Middle? & & $\begin{array}{l}\text { C36, G21b, H23, I38, K89, } \\
\text { L53a, M38, N37 }\end{array}$ \\
\hline 6 & 393 & Herr Starker Gott (K) & New? & & $\begin{array}{l}\text { C33, G22a, H24, I8, K22, } \\
\text { M8, N8 }\end{array}$ \\
\hline 6 & 393 & Reuben Weis (G) & New? & & G22b, L23b \\
\hline 6 & $\begin{array}{l}460,683, \\
771\end{array}$ & Hans Landis, Geauga (N) & Middle & & C38, G21a, H26a, K74, N40 \\
\hline 6 & 683 & Wach Auf & Old & Grünwald & $\begin{array}{l}\text { C34, G20b, H25, I4, L41b, } \\
\text { M4, N4, S10 }\end{array}$ \\
\hline 13 & 508 & & & & $\begin{array}{l}\text { G18, S30 (CHILMN list } \\
\text { extra line with 683) }\end{array}$ \\
\hline 6 & 683 & & Middle & & L53b \\
\hline 6 & 683 & Indiana Weis & New & & G20a \\
\hline 7 & $\begin{array}{l}\text { 115v4, } \\
716 \mathrm{v} 14\end{array}$ & $\begin{array}{l}\text { Grablied fur Kinder }(\mathrm{H}) \text {, } \\
\text { Viel Strenger }(\mathrm{K})\end{array}$ & New & & $\begin{array}{l}\text { C77, G31, H51, I14, K92, } \\
\text { L19a, N14 }\end{array}$ \\
\hline 7 & 155 & & New & & G16 \\
\hline 7 & 205 & $\begin{array}{l}\text { Hochzeit (Y), Stand up } \\
\text { (C), Ermuntert euch }\end{array}$ & New & Webb & C98, G30, Y6 \\
\hline 7 & 205 & & Middle? & $\begin{array}{l}\text { connected to } \\
\text { Benja Noah? }\end{array}$ & L21a \\
\hline 7 & 205 & Pit Joe & Middle? & & $\mathrm{H} 28$ \\
\hline 7 & 242 & & New? & & L22a, A26 \\
\hline 7 & 284,341 & $\begin{array}{l}\text { Lawrence, Lawrence Co. } \\
\text { (I) }\end{array}$ & New & & $\begin{array}{l}\text { C44, G36, H29, I58, K28, } \\
\text { L52, N39 }\end{array}$ \\
\hline 7 & 284,201 & Geauga & New? & & C43, H27 \\
\hline 7 & $\begin{array}{l}341,348, \\
147 \\
\end{array}$ & Sommer, Old Weis (G) & Old? & & $\begin{array}{l}\text { C46, G37, H30, I22, K27, } \\
\text { L20b, M22, N22 }\end{array}$ \\
\hline 7 & 492,205 & $\begin{array}{l}\text { Alt Merkt Auf, Gottes } \\
\text { Furcht (K) }\end{array}$ & Middle? & & $\begin{array}{l}\text { C47, G33, H31, I12, L25b, } \\
\text { M12, N12, S47, A27 }\end{array}$ \\
\hline 7 & 492 & & Middle? & & I36, M36, N36 \\
\hline 7 & $492 v 16$ & Owen Schrock (H) & New & Salvation & C78, H32, I47, M46, N51 \\
\hline 7 & $520 v 30$ & Bann Leid, Old Weis (G) & Old & & $\begin{array}{l}\text { C48, G28, H33, I32, L35b, } \\
\text { M32, N32 }\end{array}$ \\
\hline 7 & $\begin{array}{l}565, \\
520 v 7, \\
205\end{array}$ & $\begin{array}{l}\text { Benja Noah, Mose I. (I), } \\
\text { Bann Leid (G), Gerne } \\
\text { Singen (K) }\end{array}$ & Middle? & & $\begin{array}{l}\text { C49, G29, H34, I5, L39a, } \\
\text { M5, N5,38, A20 }\end{array}$ \\
\hline 7 & 623,348 & Berg & Old & Hassler & $\begin{array}{l}\text { C50, G34, H35, I7, K27, } \\
\text { L27?, M7, N7, S13, A21 }\end{array}$ \\
\hline 7 & 692 & Fußwasch Leid & Old & & $\begin{array}{l}\text { C52, G32, H36, I21, K91, } \\
\text { L42b, M21, N21, A5 }\end{array}$ \\
\hline 7 & 716v14 & $\begin{array}{l}\text { Johnny Yoder, Train Weis } \\
(\mathrm{G})\end{array}$ & New & & C42, G35, Y47 \\
\hline 7 & 716v14 & & New & & I57, M56 \\
\hline 9 & 316 & Hickory & Middle? & & C53, H37, I63, K94, L25a \\
\hline 9 & 316 & Kansas (Christner) & New & & I44, M43 \\
\hline
\end{tabular}




\begin{tabular}{|c|c|c|c|c|c|}
\hline 9 & 481 & Brush Run & Middle & $\begin{array}{l}\text { Es ist gewisslich } \\
\text { an der Zeit }\end{array}$ & Y45 \\
\hline 9 & $\begin{array}{l}512, \\
324 \mathrm{v} 4\end{array}$ & R.P. Weis & New & Restoration & C54, H38, I45, M44 \\
\hline 9 & 541 & Reuben Weis & New & & I61 \\
\hline 9 & 604 & Christlicher Lehr (K) & Old & & $\begin{array}{l}\text { C55, G11, H39, I3, K32, } \\
\text { L39b, M3, N3, S16, A18, } \\
\text { Ho124 }\end{array}$ \\
\hline 9 & $\begin{array}{l}\text { 786, 324, } \\
512\end{array}$ & $\begin{array}{l}\text { Scheid Lied, Lebt } \\
\text { friedsam (K) }\end{array}$ & New & $\begin{array}{l}\text { The Church's } \\
\text { Desolation }\end{array}$ & $\begin{array}{l}\text { C56, G13, H40, I27, K29, } \\
\text { L56, M27, N27, S[35] }\end{array}$ \\
\hline 9 & 786, 879 & Dritte Lied & Middle? & & C58, G9, H50 \\
\hline 10 & $\begin{array}{l}359, \\
278 v 11 \\
475\end{array}$ & Wort der Wahrheit (K) & Old & & $\begin{array}{l}\text { C60, G17, H41, I15, K54, } \\
\text { L28, M15, N15, S28, A14 }\end{array}$ \\
\hline 5 & $404 \mathrm{v} 17$ & & & & H lists with 359 \\
\hline 8 & 278v11 & & & & IMN list with 359 \\
\hline 19 & 408 & & & & $\begin{array}{l}\text { L30, S15, A16, CHINM list } \\
\text { extra line with } 359\end{array}$ \\
\hline & 265 & & & & $\begin{array}{l}\text { C62, A12, (HILMN list with } \\
359\end{array}$ \\
\hline 12 & 41455 & Old Weis (G) & New & & C64, G25, H42, Y44, A10 \\
\hline 12 & 41455 & & New & Newark & $\begin{array}{l}\text { C66, G26, H43, I25, K98, } \\
\text { M25, N25 }\end{array}$ \\
\hline 12 & 414 & & New & & L32 \\
\hline 13 & 508 & & Middle? & & L36, A35, Y30 \\
\hline 14 & 591 & & Old? & & L40 \\
\hline 15 & 352 & Lancaster Weis (Y) & New? & & G24, L23a, Y43 \\
\hline 16 & 302,489 & $\begin{array}{l}\text { Groß Gemein Weis, } \\
\text { Brotbrechen }(\mathrm{K})\end{array}$ & Middle? & & $\begin{array}{l}\text { C68, G54, H44, I19, K33, } \\
\text { L16b, M19, N19, A7 }\end{array}$ \\
\hline 18 & 501 & & Middle & Gott rufet noch & C69, H45 \\
\hline 18 & 501 & & Middle? & & I41, L35a, M40a \\
\hline 18 & 662, v14 & Danny Shetler (Y) & New & & I35, L42a, M35, N35, Y46 \\
\hline 19 & 706,563 & $\begin{array}{l}\text { Siebenhundertsechs, } \\
\text { Wagner (K) }\end{array}$ & Old? & & $\begin{array}{l}\text { C30, G51, H22, I3, K62, } \\
\text { L44, M13, N13, S32 }\end{array}$ \\
\hline \multirow[t]{11}{*}{20} & 783 & & Middle & & L45b, A3 \\
\hline & 791 & $\begin{array}{l}\text { Scheid Lied, Denket } \\
\text { Meiner (K) }\end{array}$ & Middle & 6thPsalm & $\begin{array}{l}\text { C70, G14, H46, I29, K79, } \\
\text { L50, M29, N29, S31, A9 }\end{array}$ \\
\hline & 793 & & Middle? & & L46b, A23 \\
\hline & 793 & Segen Wunsch & New & (spliced together) & K58 \\
\hline & 796 & Sing'n Im Sinn (K) & Middle? & & $\begin{array}{l}\text { C71, G58, I33b, K84, L44, } \\
\text { N43b, S33, A24b }\end{array}$ \\
\hline & 796 & O Seele Säume Nicht & New & & N43 \\
\hline & 802 & & Middle? & & $\begin{array}{l}\text { C72, G15, H47a, I19, 40, } \\
\text { L47b, M9, 39, N9a }\end{array}$ \\
\hline & 802 & & Middle? & & C73, H47b, 142b, M41b \\
\hline & 806 & Haslibach Lied & New? & & C74, G40, H48, L48, M57 \\
\hline & 806 & Bush Weis & New & & G38 \\
\hline & 806 & Old Weis & Middle? & & G39 \\
\hline
\end{tabular}




\section{Table 2: Tunes used with Unparteiische Leidersammlung (B) Texts}

\begin{tabular}{|c|c|c|c|}
\hline Page & Tune Name & Source & Notabuch Location \\
\hline 1 & Florida & & Y1 \\
\hline 4 & & Parting Hand & Y2 \\
\hline 5 & Loblied tune & The Great Physician & N48 \\
\hline 8 & Tiefer Not & Wort der Wahrheit & K8 \\
\hline 54 & Frühjahr (C), Sommer(Y) & & C32, Y5 \\
\hline 87 & Sonntag Schul & & K75 \\
\hline 87 & & Will the Roses Bloom in Heaven & N50 \\
\hline 88 & & Salvation & C78, I47, M46, N51 \\
\hline 92 & $\begin{array}{l}\text { Hochzeit (Y), Ermuntert euch, } \\
\text { Stand up (C) }\end{array}$ & Webb & C98, G30, Y6 \\
\hline 92 & Ein andre Weis & & G7 \\
\hline 117 & & Precious Name & Y8 \\
\hline 122 & & Must I Go and Empty-handed & Y9 \\
\hline 131a, 155 & & & I49a, M48 \\
\hline 131 & Immanuel & & K38 \\
\hline 140 & & Sandell & Y10 \\
\hline 142 & Jesum Denken & Green Fields & K76 \\
\hline 143v11 & Hochzeit & Hebron & C80, G2, Y11 \\
\hline $143 v 11$ & Hochzeit & & Y12 \\
\hline 150 & Wir Singen Dir Immanuel & & N47a \\
\hline 150 & & & N47b \\
\hline 150,149 & Alte Kinder Grab Lied & Old Hundred & I49b, M48b, Y13 \\
\hline 153 & & & H51a \\
\hline 156 & Sugarcreek Weis & Sessions & C81, Y14 \\
\hline 156 & Ein Alte Weis & & Y15 \\
\hline 158 & My Heavenly Home & My Heavenly Home & C82 \\
\hline 160 & Neu Jahr 1 & Atwater & C83 \\
\hline 160 & Neu Jahr 2 & Mear & C84, Y16 \\
\hline 173 & $\begin{array}{l}\text { Now the Hour of Worship O'er } \\
\text { (C), Nun Gott Lob (K) }\end{array}$ & Nashville & C85, K77, S22, Y17 \\
\hline 177 & Knupften Band & & K93 \\
\hline 179 & & & Y18 \\
\hline 183,189 & $\begin{array}{l}\text { Grab Lied (N), Gute Nacht at } \\
\text { Leicht (G), Jesus, Jesus (C), } \\
\text { Teure Kinder (K) }\end{array}$ & Greenville & $\begin{array}{l}\text { C88, G57, K78, M49, } \\
\text { N46, Y22 }\end{array}$ \\
\hline 189 & Grab Lied & Geneva 42 & C86, H52, K95 \\
\hline 189 & & & I50, 51, M50 \\
\hline 192 & & & I42, M51, N45 \\
\hline 194 & Hundert Weis & & Y19 \\
\hline 196 & & Sternenzahl & Y20 \\
\hline 199 & Ein Alte Weis (Y), Demut (K) & $\begin{array}{l}\text { Paradise, (Womit soll ich dich wohl } \\
\text { loben) }\end{array}$ & $\begin{array}{l}\text { C90, I53, K79, M52, } \\
\text { N44, Y21 }\end{array}$ \\
\hline 203 & & Komm o komm, O Geist des Lebens? & Y23 \\
\hline 206 & $\begin{array}{l}\text { Hochzeit Weis, Schicket Euch } \\
(\mathrm{K})\end{array}$ & Komm o komm, O Geist des Lebens & C92, K50, Y24, A46 \\
\hline
\end{tabular}




\begin{tabular}{llll}
214 & Segen Bitt A & & K52 \\
\hline 215 & Segen Bitt B & & K80 \\
\hline 220,216 & Alt Ernte (C), Ernte (K) & The Church's Desolation? & $\begin{array}{l}\text { C94, I37, 39, K53, M37, } \\
\text { N42, S94, Y25, A58 }\end{array}$ \\
& & & K81 \\
\hline 220 & Nahe Mein Ende & Dir, dir Jehovah & 141b, M40b \\
\hline 227 & & & C96, G55, K82, Y26, \\
\hline 238 & Hochzeit Lied, Wachet Auf (K) & Wachet auf & A40 \\
& & & Y27 \\
\hline 239 & Wach Lied & Near the Cross & Y28 \\
\hline 243 & & Bound Brook & Y29 \\
\hline 249 & & Wach Lied & Y32 \\
\hline 263 & Wach Lied & St. Petersburg & Y33 \\
\hline 270 & Ein Alte Weis & Was Gott tut, das ist wohlgetan & C100, I46, K83, Y38 \\
\hline 276 & & & Y34 \\
\hline 278 & & & C71, G58, I33b, K84, \\
\hline 286 & Sing'n Im Sinn (K) & & L44, N43b, S33, A24b \\
\hline 286 & & Crambambuli & Y35 \\
\hline 288 & & & Y40 \\
\hline 314 & & Grosser Gott, wir loben Dich & Y40 \\
\hline 327 & & & \\
\hline
\end{tabular}

Table 3: Tunes used with Unparteiische Leidersammlung (G) Texts

\begin{tabular}{|c|c|c|c|}
\hline Page & Tune Names & Source & Notabuch Location \\
\hline 314 & & & I54, M53 \\
\hline 457 & & Varina & I55, M54 \\
\hline 463 & & Berne & I56, M55 \\
\hline 476 & & Bethany & I59, N49 \\
\hline
\end{tabular}

\section{Endnote}

${ }^{1}$ Gracia Schlabach (b. 1979) moved from Holmes County, Ohio, to western New York with her parents and siblings thirteen years ago. Since 2009, she has been teaching in Old Colony Mennonite schools in central Chihuahua State, Mexico. A great side benefit is the opportunity to learn (and transcribe) their slow tunes. When she is not singing, Gracia loves to study foreign languages, especially German, and grow herbs in her garden. She may be reached at 2784 Murdock Rd., Medina, NY 14103. 


\section{References}

Durnbaugh, Hedwig T. 1998. "The Amish Singing Style: Theories of its Origin and Description of its Singularity.” Journal of the Center for Pennsylvania German Studies 5(3):2-9.

Hohmann, Rupert Karl. 1959. The Church Music of the Old Order Amish of the United States. Doctoral dissertation in Music History and Uterature. Evanston, IL: Northwestern University.

Jackson, George Pullen. 1945. “The Amish Sing Medieval Hymn Tunes Today.” Southern Folklore Quarterly 10(2):151-57.

Jackson, George Pullen. 1945. "The Strange Music of the Old Order Amish.” The Musical Quarterly 31(3):275-88.

Nettl, Bruno. 1957. "The Hymns of the Amish: An Example of Marginal Survival.” Journal of American Folklore 70(278):323-28.

Riall, Robert. (n.d.). First Sorrow, Then Joy. Unpublished manuscript.

Schlabach, Gracia. 2011. Metrisches Register fur das Ausbund. Medina, NY: The Lilting Leaf.

Schlabach, Gracia. 2011. Now Thank We All Our God. Medina, NY: The Lilting Leaf.

Schlabach, Gracia. 2012. The Ausbund: What do the Amish Sing? Medina, NY: The Lilting Leaf.

Sommers, Ernst. 1972. Jahrbuch für Liturgik und Hymnologie. 17: 100-64.

Temperley, Nicholas. 1981. "The Old Way of Singing.” Journal of the American Musicological Society 34(3):511-44.

Umble, John. 1939. “The Old Order Amish, Their Hymns and Hymn Tunes.” Journal of American Folklore 52(203):82-95.

Wagler, David L 1985. “The History of our Amish Church Tunes.” Family Life December:1519.

Yoder, Joseph W. 1942. Amische Lieder. Huntingdon, PA: The Yoder Publishing Company.

Yoder, Paul M., Elizabeth Bender, Harvey Graber, and Nelson P. Springer. 1964. Four Hundred Years with the Ausbund. Scottdale, PA: Herald Press. 